\title{
A Comparison of Various Ecological Indexes for Environmental Assessment of Vulnerable Mountain Ecosystems
}

\author{
Nurzat Totubaeva $^{1 *}$, Zhiide Tokpaeva ${ }^{1}$, Kanatbek Kojobaev ${ }^{1}$, \\ Gulbubu Kurmanbekova \\ ${ }^{1}$ Department of Environmental Engineering, Kyrgyz-Turkish Manas University, Bishkek, Kyrgyz Republic \\ ${ }^{2}$ Department of Biology, Kyrgyz-Turkish Manas University, Bishkek, Kyrgyz Republic
}

Received: 29 March 2019

Accepted: 29 May 2019

\begin{abstract}
The aim of this work was to compare various ecological indexes to assess the state of urbanized ecosystems of the Issyk-Kul region in the Kyrgyz Republic. Soil samples were analyzed for Pb, Zn, Fe, $\mathrm{Cu}$ and $\mathrm{Cd}$ using AAS. Heavy metal contamination status was assessed using indexes for enrichment factor, geo accumulation, contamination factor, degree of contamination, pollution load, potential ecological risk and integrated risk using the Triad approach. Results show marked variations of heavy metal concentrations within the study area. The concentrations of heavy metals in soils of Issyk-Kul had the following increasing order: $\mathrm{Zn}>\mathrm{Pb}>\mathrm{Cu}>\mathrm{Cd}$. Indexes such as enrichment factor and contamination factor showed the Issyk-Kul soils to be moderately polluted with $\mathrm{Pb}, \mathrm{Zn}$ and $\mathrm{Cd}$; geoacumulation revealed extreme contamination with $\mathrm{Pb}, \mathrm{Zn}$ and $\mathrm{Cu}$. Potential ecological risk estimated low risk, while the Triad approach characterized soil as highly contaminated. The Triad approach shows that using biotic components in evaluating the contamination degrees is informative. The results of this study show that adequate measures should be put to checkmate and regulate human activities around Issyk-Kul Lake in order to protect soil from further deterioration and contamination.
\end{abstract}

Keywords: soil, heavy metals, ecological indexes, Triad approach, Issyk-Kul

\section{Introduction}

Heavy metals are the most significant pollutants in the environment [1]. There are two main sources of their income: natural content of heavy metals in rocks and technogenics caused by vigorous activities in the

*e-mail: totubaevanurzat@gmail.com,

mining industry [2-3], enterprises of the metallurgical complex, motor vehicles [4-6], thermal power plants, waste incineration, and waste water [7]. Soil, which has a pronounced cationic absorption capacity, is a powerful accumulator of heavy metals. Soil that has a pronounced cationic absorption capacity is a powerful accumulator of heavy metals. Therefore, their constant supply even in small quantities for a long time can lead to a significant accumulation of them in the soil and their further geochemical transport [8-9]. 
Issyk Kul is one of the developed regions of the Kyrgyz Republic. Industrial, agricultural and tourism sectors are developed in this region. Around 4 million tourists a year visit this area, and $70 \%$ of them take part in beach holidays on Issyk-Kul Lake [10]. The KadzhiSay uranium tailing dumps, Kumtor gold complex, and Dzhergalan coal mine are located in the Issyk-Kul region, which is also an important transportation hub, with road leading to Kazakhstan and China. IssykKul was included in the list of wetlands in 1986 and therefore is of great importance for ensuring the habitat of waterfowl.

During the Soviet period, exploration of mineral resources such as uranium and gold, etc., was actively conducted in the Issyk-Kul region, which adversely affected the ecological well-being of the region and the health of the population [11-12]. Currently, uneven recreational and economic activities, as well as uneven use of resources, pose a potential threat to the unique ecosystem of Issyk-Kul, which was included in the list of wetlands and therefore takes great importance for ensuring the habitat of waterfowl. Therefore, the assessment of the soil in this region is a priority. In this regard, the purpose of this work was to compare various ecological indexes for assessing the Issyk-Kul ecosystem.

\section{Material and Methods}

\section{Study Area}

The Issyk-Kul region is located in the northeastern part of the Kyrgyz Republic where it borders with Kazakhstan and in the southeast with China. The entire region is the Issyk-Kul biosphere territory, which has earned official recognition from UNESCO and was included in the World Network of Biosphere Reserves in September 2001. The resort, agro-industrial and mining sectors are well developed in the region and the potential risk of environmental pollution is serious.

\section{Sampling}

The region was conventionally divided into four zones (western, eastern, northern and southern) to identify the most enhanced anthropogenic effect on the soil. A total of 28 soil samples were collected (Fig. 1). Each soil sample was taken at a depth of 0-20 cm from five different points and combined into one composite sample. The samples were placed in labeled polyethylene bags and transported to the laboratory for subsequent preparation for analysis.

In the laboratory, all samples were air-dried at room temperature and sieved through a 2-mm sieve. 1 gram of soil samples were digested with $15 \mathrm{ml}$ concentrated hydrochloric acid (HCL) and $5 \mathrm{ml}$ of concentrated nitric acid. The mixtures were heated, distilled water was added to the digested sample and then filtered with a Whatman filter paper and topped up in a $100 \mathrm{ml}$ volumetric flask with distilled water. Then concentrations of $\mathrm{Pb}, \mathrm{Cd}, \mathrm{Zn}, \mathrm{Cu}, \mathrm{Fe}$ in the soil samples were analyzed using atomic absorption spectrophotometry (MGA-915).

\section{Statistical Data Analysis}

Mean and standard error were computed from triplicates of soil physico-chemical parameters using the Statistical Package for Social Sciences (SPSS 20.0).

\section{Estimating Pollution Level}

To evaluate the level of soil contamination with heavy metals, different indexes were calculated: enrichment factor (EF), geoaccumulation index (Igeo),

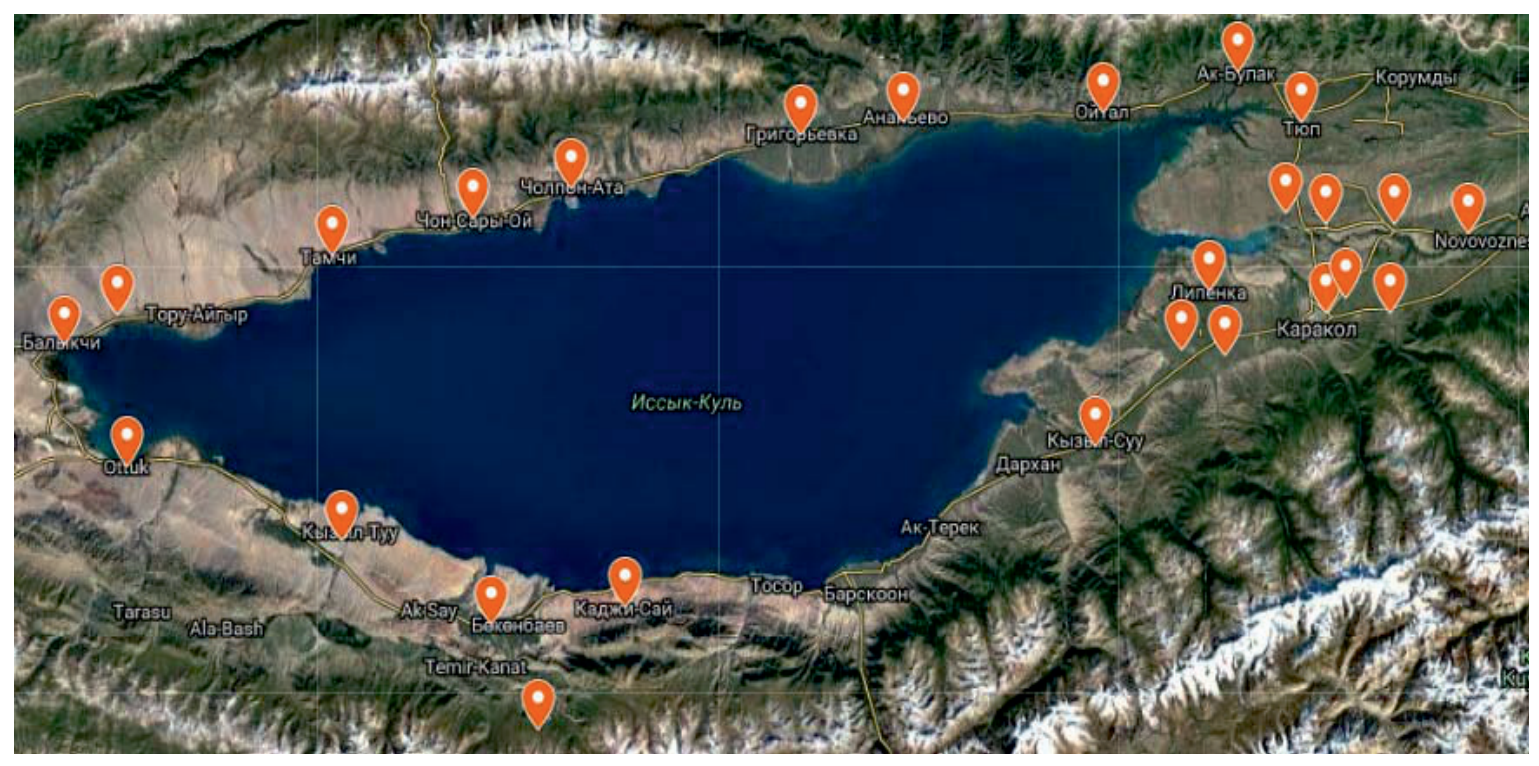

Fig. 1. Location of study area. 
contamination factor $(\mathrm{CF})$, contamination degree (Cd), potential ecological risk index (PER) and ecological risk index (RI) by Triad approach.

The enrichment factor (EF) was a parameter to evaluate the influence of human activities on the concentration of heavy metals in soil. EF is defined by the following equation (1):

$$
E F=\left(C_{X} / C_{F e}\right) \text { sample } /\left(C x / C_{F e}\right) \text { background }
$$

...where $\mathrm{Fe}$ (iron) is chosen as a natural element of reference [13-14], $\left(\mathrm{C}_{\mathrm{X}} / \mathrm{C}_{\mathrm{Fe}}\right)$ sample is the ratio between concentration of the element " $\mathrm{X}$ " and that of $\mathrm{Fe}$ in the soil sample; and $\left(\mathrm{C}_{\mathrm{X}} / \mathrm{C}_{\mathrm{Fe}}\right)$ background is the ratio between concentration of the element " $\mathrm{X}$ " and that of $\mathrm{Fe}$ in unpolluted reference baseline. Degrees of enrichment factor were classified into five categories [15-16]: $\mathrm{EF}<2$, minimal enrichment; $2<\mathrm{EF}<5$, moderate enrichment; $5<\mathrm{EF}<20$, significant enrichment; $20<\mathrm{EF}<40$, very high enrichment; and $\mathrm{EF}>40$, extremely high enrichment.

The geoaccumulation index (Igeo) was used to assess the pollution intensity of heavy metals in the soil, which was expressed as follows (2):

$$
\operatorname{Igeo}=\log _{2}(\mathrm{Cn} / 1.5 \mathrm{Bn})
$$

...where $\mathrm{Cn}$ is the concentration of the metal in analyzed soil; $\mathrm{Bn}$ is the background concentration of the same metal and the factor 1.5 is the background matrix correction factor. Recommended by Müller [17], the values of Igeo are interpreted as: Igeo $<0$, unpolluted; $0 \leq$ Igeo $<1$, unpolluted to moderately polluted; $1 \leq$ Igeo $<2$, moderately polluted; $2 \leq$ Igeo $<3$, moderately to heavily polluted; $3 \leq$ Igeo $<4$, heavily polluted; $4 \leq$ Igeo $<5$, heavily to extremely polluted; and Igeo $\geq 5$, extremely polluted.

Contamination factor $(\mathrm{CF})$ is calculated by dividing the concentration of elements in the soil by the background concentration [18]. CF is calculated with the following equation (3):

$$
C F=\text { CmSample / CmBackground }
$$

...where CmSample refers to the concentration of a given metal in soil and CmBackground refers to the value of a reference metal, which is the value of the metal in the average shale. The $\mathrm{CF}$ values are categorized into 4: $\mathrm{CF}<1$ indicates low contamination; $1 \leq \mathrm{CF}<3$ is moderate contamination; $3 \leq \mathrm{CF}<6$ is considerable contamination; and $\mathrm{CF}>6$ is very high contamination.

To facilitate pollution control, Hakanson [18] proposed a diagnostic tool named as degree of contamination. $\mathrm{C}_{\mathrm{d}}$ and it is determined as the sum of the $\mathrm{CF}$ for each sample (4):

$$
C d=\Sigma C F
$$

The classification of the degree of contamination $\left(\mathrm{C}_{\mathrm{d}}\right)$ in soil [18]: $\mathrm{C}_{\mathrm{d}}<6$ low degree of contamination; $6<\mathrm{C}_{\mathrm{d}}<12$ moderate degree of contamination; $12<\mathrm{C}_{\mathrm{d}}<24$ considerable degree of contamination; and $\mathrm{C}_{\mathrm{d}}>24$ high degree of contamination.

Pollution load index (PLI) for a set of $n$ polluting elements is defined as a value calculated from the geometric mean of the contamination factors of those elements. PLI is calculated by the following expression given by Tomlinson et al. [19] (5):

$$
P L I=(C F 1 x C F 2 x C F 3 x \ldots \ldots C F n)^{1 / n}
$$

PLI value higher than unity suggests pollution existence, while lower than 1 indicates no pollution load.

The potential ecological risk (PER) was employed to evaluate the eco risk of heavy metals in soil [17] (6, 7):

$$
\text { Cif }=C i / C i n
$$

$$
P E R=\text { Tir } \times \text { Cif }
$$

$$
P E R I=\sum P E R C d=\Sigma C F,
$$

...where Tir is the toxic response coefficient for a given heavy metal, and $\mathrm{Cif}$ is the contamination factor, $\mathrm{Ci}$ is the concentration of measured metals and Cin is a background values of heavy metals. The toxic response coefficient of $\mathrm{Cd}, \mathrm{Cu}, \mathrm{Pb}$ and $\mathrm{Zn}$ is 30, 5, 5 and 1, respectively [20]. PERI (8) is the sum of all PER calculated for each metal inside one area. The classification of potential eco-risk is as follows [20]: $\mathrm{RI}<150$ low risk, $150 \leq \mathrm{RI}<300$ moderate risk, $300 \leq \mathrm{RI}<600$ considerable risk, and $\mathrm{RI} \geq 600$ very high ecological risk.

According to Dagnino A. [21-22], equations used to calculate the indexes of soil status by the Triad approach are presented in Table 1 .

\section{Bioindication - Ecological Risk Index (EcoRI)}

The number of microorganisms was determined by the plate method. Ten grams of each soil sample were added to $90 \mathrm{~mL}$ of distilled water. The solution was diluted $\left(10^{-1}\right.$ to $\left.10^{-6}\right)$ and aliquots of the resulting solutions plated on appropriate culture media. Czapek media was used for fungal growth, meat-peptone agar (MPA) for bacteria growth and starch-ammonia agar (SAA) for actinomycetes growth. All experiments were performed in triplicate. After incubation at 25 or $30^{\circ} \mathrm{C}$, for up to 10 days, the colony forming units (CFU) were counted. 
Table 1. Equations used to calculate the indexes of soil status on the basis of chemical, toxicological and bioindication characteristics according Dagnino A. [21]

\begin{tabular}{|c|c|c|}
\hline $\begin{array}{l}\text { Comparison of data on contaminated and } \\
\text { background samples }\end{array}$ & $\begin{array}{l}\text { Calculation of the indices } \\
\text { of soil state by ith component }\end{array}$ & $\begin{array}{l}\text { Integration of data on ith } \\
\text { into the index of soil state }\end{array}$ \\
\hline \multicolumn{3}{|c|}{ Index of soil state as based on the chemical indicators (IC) } \\
\hline$C i \leq$ Cbackgr. $i$ & $I C i=(C i /$ Cbackgr. $) 0.50$ & \multirow{3}{*}{$I C=\sum_{i=1}^{n} I C i / n$} \\
\hline$\tilde{N b a c k g r .} . i<C i \leq 10 M P C i$ & $I C i=0.5+\left(\frac{C i-\text { Cibackgr. } i}{10 M P C i-\text { Cbackg.i }}\right) \times 0.5$ & \\
\hline $10 \mathrm{MPCi}<\mathrm{Ci}$ & $I C x i=1$ & \\
\hline \multicolumn{3}{|c|}{ Index of soil state as based on the toxicological indicators (IT) } \\
\hline$\frac{\mid \text { Ti-Tbackg.i } \mid}{\text { Tbackg.i }} \leq 0.20$ & $I T i=0$ & \multirow{3}{*}{$I T=\frac{\sum_{i=1}^{n} I T i}{n}$} \\
\hline$I B=\frac{\sum_{i=1}^{n} I B i}{n}$ & $I T i=\frac{\frac{\mid \text { Ti-Tbackg. } i \mid}{\text { Tbackg.i }}-0.20}{0.80-0.20}$ & \\
\hline $0.80<\frac{\mid \text { Ti-Tbackg.i } \mid}{\text { Tbackg.i }}$ & $I T i=1$ & \\
\hline \multicolumn{3}{|c|}{ Index of soil state as based on bioindication (IB) } \\
\hline$\frac{\mid \text { Bi-Bbackg. } i \mid}{\text { Bbackg.i }}=0$ & $I B i=0$ & \multirow{3}{*}{$I B=\frac{\sum_{i=1}^{n} I B i}{n}$} \\
\hline $0<\frac{\mid \text { Bi-Bbackg. } i \mid}{\text { Bbackg.i }} \leq 0.80$ & $I B i=\frac{\frac{\mid \text { Bi-Bbackg.i } \mid}{\text { Bbackg.i }}}{0.80}$ & \\
\hline $0.80<\frac{\mid B i-\text { Bbackg. } i \mid}{\text { Bbackg.i }}$ & $I B i=1$ & \\
\hline
\end{tabular}

$\mathrm{Ci}$ is the concentration of the ith chemical substance in the sample; $\mathrm{C}$ backg.i is the concentration of the ith chemical substance in the background soil; $\mathrm{Ti}$ is the value of test function of the ith biotest in thesample; T backgr.iis the value of test function of the ith biotest in the background sample; $\mathrm{Bi}$ is the value of test function of the ith bioindicator in the sample; $\mathrm{B}$ backgr.i is the value of test function of the ith biotest in the background sample; and nis the number of studied characteristics. MPC for $\mathrm{Zn}, \mathrm{Cd}, \mathrm{Pb}$ and $\mathrm{Cu}$ is $23,2,6$ and 3 respectively according Kyrgyz Republic standards.

\section{Bioassay - Ecotoxicological Risk Index (EtoxRI)}

Phytotoxicity tests were conducted according to Terekhova et al. [23] using monocotyledonous plant oat (Avena sativa L.) and dicotyledonous plants - radish (Raphanus sativus L.) and cress (Lepidium sativa). A phytotoxicity test was carried out in phytoplates, in modification of soil ecotoxicological analysis laboratory, Lomonosov Moscow State University.

The following endpoints were measured to evaluate phytotoxicity: seed germination (\%), shoot length $(\mathrm{mm})$, and root length $(\mathrm{mm})$. Plants that did not germinate were not considered in the subsequent analysis of growth. Phytotoxic effect (PE) can be calculated using different approaches. More commonly used indicators of germination of seeds. Phytotoxic effect PE (\%) is calculated by formula (9):

$$
P E(\%)=\left(\frac{R_{\text {control }}-R_{\text {sample }}}{R_{\text {control }}}\right) \times 100 \%
$$

...where $\mathrm{R}_{\text {sample }}$ - response in samples, $\mathrm{R}_{\text {control }}$ - response in control. When evaluating the results of the tests, the following toxicity criteria were accepted: non-toxic 
Table 2. Conformity of the integral index of the ecological state, determined on the basis of the Triad approach to the categories of soil quality according to Vorobeychik [24], the degree of loading and the characterization of the ecological state according to Yakovlev [25].

\begin{tabular}{|c|c|c|c|}
\hline Conformity of index & Soil quality category & Degree of load & $\begin{array}{c}\text { Characterization of the eco- } \\
\text { logical state of the soil }\end{array}$ \\
\hline $\mathrm{CI}=0$ & I & Permissible & Background \\
\hline $0 \leq \mathrm{CI} \leq 0.30$ & II & Low & Slightly disturbed \\
\hline $0.30<\mathrm{CI} \leq 0.50$ & III & Average & Severely disturbed \\
\hline $0.50<\mathrm{CI} \leq 0.79$ & IV & High & Irreversibly disturbed \\
\hline $0.79<\mathrm{CI} \leq 1$ & V & Very high & \\
\hline
\end{tabular}

samples IT $<10 \%$; low-toxic samples $10 \%<\mathrm{IT}<50 \%$; toxic samples $50 \%<\mathrm{IT}<100 \%$; and highly-toxic samples IT $=100 \%$.

A chemical risk index (ChemRI), ecotoxicological risk index (EtoxRI), and ecological risk index (EcoRI) in the range $0-1$, were calculated according to Dagnino et al. [21]. The data were analyzed by comparing the results from investigated sites with those from the low-contaminated control site $(10 \mathrm{~m})$ and by computing the risk indexes for each parameter. Finally, the integral risk index (RI) (10) was calculated by applying weighting factors based on the ecological relevance of the different data (eq. 1): 1, 1.5 and 2, respectively for ChemRI, EtoxRi and EcoRI.

$$
R I=\left(\frac{\text { ChemRI } \times 1+\text { Etox } \times 1.5+E c R I * 2.0}{1+1.5+2.0}\right)
$$

\section{Results and Discussion}

The content of lead, cadmium, copper and zinc in the soil samples of the studied zones are presented in Table 3.

The heavy metal contents in soils of the Issyk-Kul region shown in Table 3 reveals that $\mathrm{Zn}$ and $\mathrm{Pb}$ were higher in values in all studied zones, while $\mathrm{Cu}$ and $\mathrm{Cd}$ values were lower in the western zone. Fig. 2 shows the mappings of spatial spread distribution of $\mathrm{Co}, \mathrm{Cu}, \mathrm{Pb}$, and $\mathrm{Zn}$ in soil. The red colors show the higher heavy metals concentrations in geochemical maps, whereas the green colors indicated low concentrations. The distribution patterns of $\mathrm{Co}$ and $\mathrm{Cu}$ indicated low spatial heterogeneity and their abundances very little in study area. There were some clear heavily polluted hot spots with higher levels of $\mathrm{Pb}$ and $\mathrm{Zn}$, located mainly in the northern and eastern parts of the study area. Based on maps, the highest concentrations of the selected heavy metals in the soil samples were found in the vicinity of industrial activities, such as transport and agriculture.

The enrichment values of the study areas are shown in Table 4. The enrichment factors in the western zone followed this order: $\mathrm{Pb}(2.41)>\mathrm{Cu}$ (1.29)> $\mathrm{Zn} \mathrm{(1.14)>}$ $\mathrm{Cd}$ (0.98). In all other zones, the enrichment factor values followed this sequence: $\mathrm{Pb}>\mathrm{Cd}>\mathrm{Cu}>\mathrm{Zn}$. In the western zone, $\mathrm{Pb}$ had the highest enrichment factor and classified the soil as moderately enriched with $\mathrm{Pb}$. Based on the classification, the values obtained for the enrichment factors of $\mathrm{Cu}, \mathrm{Zn}$ and $\mathrm{Cd}$ in the western zone were lower than $2(\mathrm{EF}<2)$, which is a reflection of a minimal enrichment. On the basis of enrichment factor, the other investigated soils were minimally enriched with $\mathrm{Pb}, \mathrm{Cd}, \mathrm{Cu}$ and $\mathrm{Zn}$ except in northern and southern soils, which were unpolluted with $\mathrm{Zn}$.

The calculated Igeo values for toxic metals of soils collected from four zones of Issyk Kul are illustrated in Table 5. In all the zones, the Igeo values followed this order: $\mathrm{Zn}>\mathrm{Pb}>\mathrm{Cu}>\mathrm{Cd}$. Generally, $\mathrm{Zn}, \mathrm{Pb}$ and $\mathrm{Cu}$ had the highest Igeo index values for all study areas. The highest value of geoacumulation index $\mathrm{Pb}$ is observed in the western zone (8.85) and the southern zone (8.73), and $\mathrm{Zn}$ in the eastern zone (10.91) and in the southern zone (10.81). Based on the geoacumulation index, in all zones soil is classified as very polluted with $\mathrm{Zn}, \mathrm{Pb}$ and $\mathrm{Cu}$. Negative values observed for $\mathrm{Cd}$ are a result of deficient low levels of contamination.

Table 3. Mean values of heavy metals in the soil.

\begin{tabular}{|c|c|c|c|c|c|}
\hline Issyk-Kul zones & $\mathrm{Pb}$ & $\mathrm{Cd}$ & $\mathrm{Cu}$ & $\mathrm{Zn}$ & $\mathrm{Fe}$ \\
\hline Western zone & $32 \pm 3,27$ & $0,3 \pm 0,08$ & $18 \pm 1,63$ & $60 \pm 5,89$ & $233 \pm 7,89$ \\
\hline North Zone & $28,5 \pm 8,28$ & $0,55 \pm 0,29$ & $22 \pm 3,21$ & $61,3 \pm 13,46$ & $316,7 \pm 5,87$ \\
\hline South Zone & $29,4 \pm 8,82$ & $0,56 \pm 0,21$ & $20,5 \pm 5,68$ & $65,1 \pm 5,21$ & $342,5 \pm 4,19$ \\
\hline East Zone & $24,6 \pm 4,44$ & $0,55 \pm 0,15$ & $21,4 \pm 4,82$ & $69,9 \pm 6,62$ & $308,6 \pm 7,87$ \\
\hline Background & $21,7 \pm 9,61$ & $0,50 \pm 0,15$ & $22,7 \pm 6,43$ & $41,3 \pm 10,26$ & $380 \pm 9,87$ \\
\hline
\end{tabular}



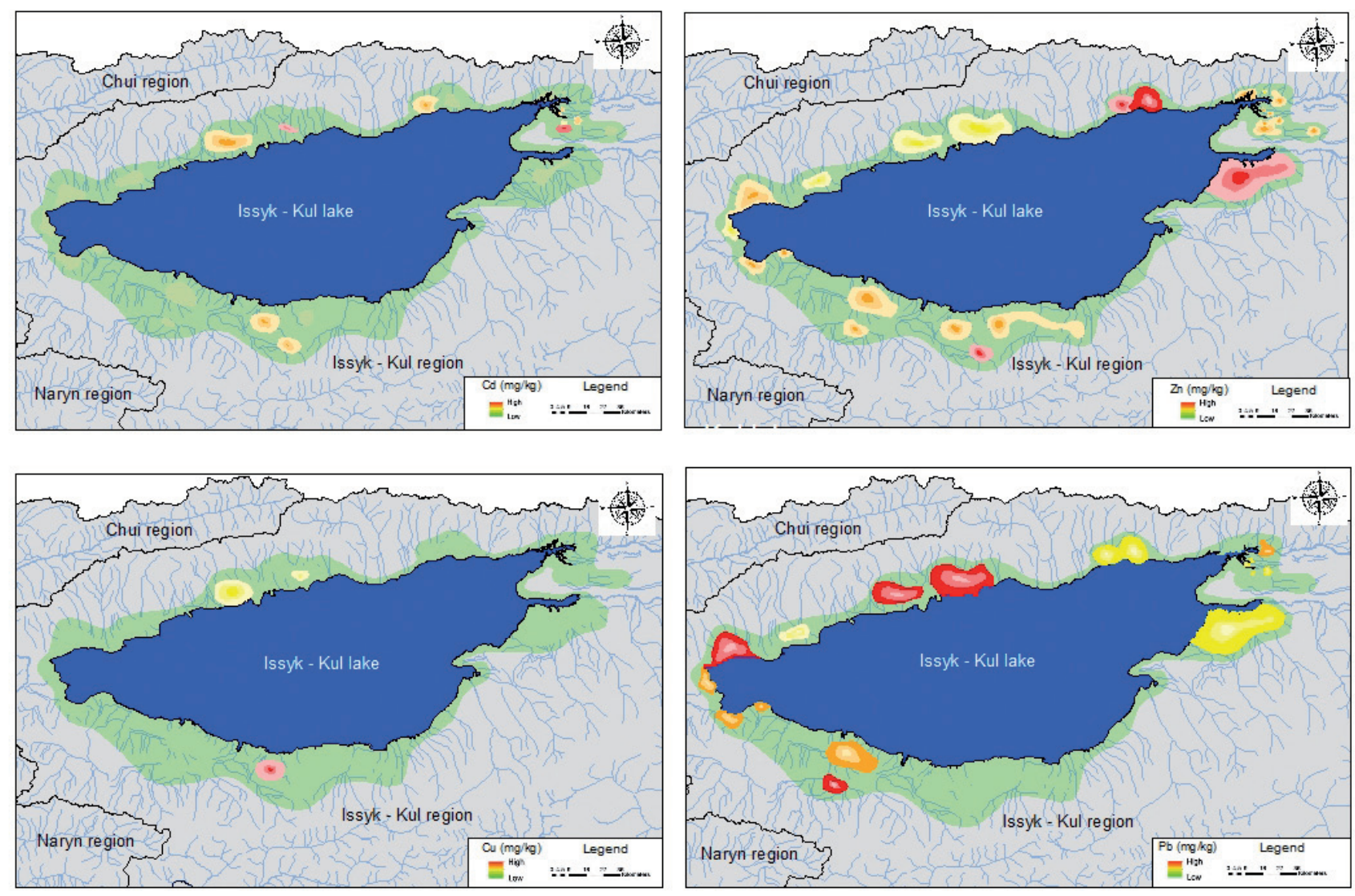

Fig. 2. Spatial distributions of heavy metals in Issyk-Kul soils.

Table 6 shows that $\mathrm{Zn}$ had high contamination values 1.69 in the eastern zone, while in other zones values ranged from 1.45-1.58, which also referred to moderate contamination. $\mathrm{Pb}, \mathrm{Zn}$, and $\mathrm{Cd}$ in all zones were classified as moderately contaminated, except in western zone soil low contaminated with $\mathrm{Cd}$. Copper

Table 4. Soil enrichment factors (EF) in the study area.

\begin{tabular}{|c|c|c|c|c|}
\hline Issyk-Kul zones & $\mathrm{Pb}$ & $\mathrm{Cd}$ & $\mathrm{Cu}$ & $\mathrm{Zn}$ \\
\hline Western zone & 2,41 & 0,98 & 1,29 & 1,14 \\
\hline North Zone & 1,58 & 1,32 & 1,17 & 0,85 \\
\hline South Zone & 1,50 & 1,24 & 1,01 & 0,84 \\
\hline East Zone & 1,40 & 1,35 & 1,17 & 1.00 \\
\hline
\end{tabular}

Table 5. Soil geoaccumulation indexes (Igeo) of heavy metals in the study area.

\begin{tabular}{|c|c|c|c|c|}
\hline Issyk-Kul zones & $\mathrm{Pb}$ & $\mathrm{Cd}$ & $\mathrm{Cu}$ & $\mathrm{Zn}$ \\
\hline Western zone & 8,85 & $-3,32$ & 8,09 & 10,69 \\
\hline North Zone & 8,69 & $-2,45$ & 8,38 & 10,72 \\
\hline South Zone & 8,73 & $-2,42$ & 8,28 & 10,81 \\
\hline East Zone & 8,48 & $-2,45$ & 8,34 & 10,91 \\
\hline
\end{tabular}

had the least contamination factor values in all zones 0.79-0.94 and was classified as low contamination. The contamination factors in the western zone in increasing order followed a similar trend: $\mathrm{Pb}>\mathrm{Zn}>\mathrm{Cu}>$ $\mathrm{Cd}$, and in the other investigated zones: $\mathrm{Zn}>\mathrm{Pb}>\mathrm{Cd}>$ $\mathrm{Cu}$.

According to the degree of soil contamination, Issyk-Kul is classified as slightly contaminated by heavy metals. Contamination degree values are 4.32; 4.87;

Table 6. Contamination factors (CF) and degree of contamination $\left(\mathrm{C}_{\mathrm{d}}\right)$ of heavy metals in the study area.

\begin{tabular}{|c|c|c|c|c|c|}
\hline Issyk-Kul zones & $\mathrm{Pb}$ & $\mathrm{Cd}$ & $\mathrm{Cu}$ & $\mathrm{Zn}$ & Cdegree \\
\hline Western zone & 1.47 & 0.60 & 0.79 & 1.45 & 4.32 \\
\hline North Zone & 1.31 & 1.10 & 0.97 & 1.48 & 4.87 \\
\hline South Zone & 1.35 & 1.12 & 0.90 & 1.58 & 4.95 \\
\hline East Zone & 1.13 & 1.10 & 0.94 & 1.69 & 4.87 \\
\hline
\end{tabular}

Table 7. Pollution load index (PLI) of heavy metals in the study area.

\begin{tabular}{|c|c|c|c|c|}
\hline & $\begin{array}{c}\text { Western } \\
\text { zone }\end{array}$ & $\begin{array}{c}\text { North } \\
\text { Zone }\end{array}$ & $\begin{array}{c}\text { South } \\
\text { Zone }\end{array}$ & $\begin{array}{c}\text { East } \\
\text { Zone }\end{array}$ \\
\hline PLI & 0.25 & 0.52 & 0.54 & 0.50 \\
\hline
\end{tabular}


Table 8. Potential ecological risk (PRI) of heavy metals in the study area.

\begin{tabular}{|c|c|c|c|c|c|}
\hline \multirow{2}{*}{ Issyk-Kul zones } & \multicolumn{3}{|c|}{ Ei } & \multirow{2}{*}{ PERI } \\
\cline { 2 - 6 } & $\mathrm{Pb}$ & $\mathrm{Cd}$ & $\mathrm{Cu}$ & $\mathrm{Zn}$ & 30,79 \\
\hline Western zone & 7,37 & 18,00 & 3,96 & 1,45 & 45,90 \\
\hline North Zone & 6,57 & 33,00 & 4,85 & 1,58 & 46,47 \\
\hline South Zone & 6,77 & 33,60 & 4,52 & 1,69 & 45,07 \\
\hline East Zone & 5,67 & 33,00 & 4,71 & & \multirow{2}{*}{} \\
\hline
\end{tabular}

4.95 and 4.87 respectively in the western, northern, southern and eastern zones.

As can be seen from Table 7, in the studied zones PLI values varied in the range of $0.25-0.54$, which is lower than 1 and indicates no pollution load

Potential ecological risk (PERI) of selected heavy metals in soil samples has been evaluated and shown in Table 8. In all zones, potential ecological risk values ranged from 30.79 to 46.47 and recorded a low risk.

Ecological assessment of soil by the Triad method was tested only in the western zone of the Issyk-Kul region. This region is an important transport hub of the region and causes a high risk of soil contamination with heavy metals.

Studying the effect of transport pollution on soil microorganisms with a decrease in the number and species diversity of all studied groups of microorganisms was observed, except fungi, which indicate their tolerance to this type of pollution (Table 9). Actinomycetes populations were insignificant. Cinereus, Helvolo Flavus and Roseus sections were observed. The fungi strains were identified as Aspergillus, Fusarium and Penicillium.
Test cultures showed high sensitivity to heavy metals and in our study they were established in the following order: Raphanus sativus <Lepidium sativa $<$ Avéna sativa. The most sensitive were the seeds of the Raphanus sativus, in which germitation was $7 \%$ (Table 10). Heavy metals stimulated the growth of Avéna sativa seeds. However, seed germination energy of Lepidium sativa (40\%) and Raphanus sativus (7\%) was low compared to background values. Soil samples of the western zone had a noticeable inhibitory effect on the aboveground and underground parts of plants in comparison with the control parameters. A high toxicity caused by the germination of radish seeds by more than $50 \%$ was demonstrated, which confirms the greatest informativeness of biotic control of the toxicity of natural media [26-27].

Fig. 3. presents the results of chemical, toxicological and bioindication data.

The integral index calculated by the Triad approach and equal to 0.55 referred the ecological condition of the Issyk-Kul region soils to highly disturbed.

Variations were observed in the levels of heavy metal accumulation in Issyk-kul zones. The four zones

Table 9. Populations of soil microorganisms; mean and standard deviation, $\overline{\mathrm{X}} \pm \mathrm{SD}$.

\begin{tabular}{|c|c|c|c|}
\hline Soil samples & Bacteria, CFU & Fungi, CFU & Actinomycetes, CFU \\
\hline Western zone & $60 \pm 5,39$ & $24 \pm 2,89$ & $30 \pm 4,73$ \\
\hline Background & $76 \pm 4,47$ & $34 \pm 7,81$ & $88 \pm 3,37$ \\
\hline
\end{tabular}

Table 10. Germination, shoot, and root lengths for plant species; mean and standard deviation, $\overline{\mathrm{X}} \pm \mathrm{SD}$.

\begin{tabular}{|c|c|c|c|c|}
\hline Tested plants & Germination, $\%$ & Shoot lengths, $\mathrm{mm}$ & Root lengths, $\mathrm{mm}$ & $\begin{array}{c}\text { Phytotoxic effect of seeds } \\
\text { germination, } \%\end{array}$ \\
\hline \multicolumn{7}{|c|}{ Western zone } \\
\hline Lepidium sativa & 40 & $7.8 \pm 0,22$ & $9.1 \pm 0,23$ & 48 \\
\hline Avena sativa L. & 100 & $15.1 \pm 0,08$ & $15.1 \pm 0,24$ & 71 \\
\hline Raphanus sativus L. & 7 & $7.1 \pm 0.05$ & $3.5 \pm 0.03$ & 75 \\
\hline \multicolumn{7}{|c|}{ Background } \\
\hline Lepidium sativa & 77 & $15.4 \pm 0,30$ & $20.6 \pm 0,39$ & $14.2 \pm 0,55$ \\
\hline Avena sativa L. & 90 & $19.8 \pm 0,35$ & $23 \pm 0.22$ & \\
\hline Raphanus sativus L. & 27 & $17.2 \pm 0.32$ & & \\
\hline
\end{tabular}




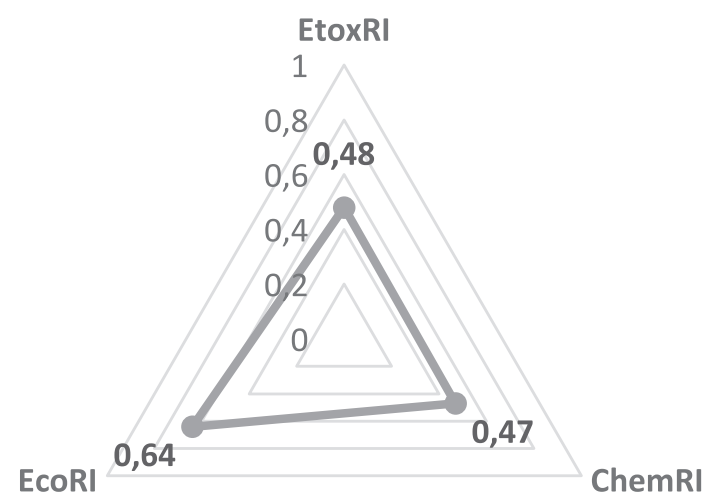

Fig. 3. Calculated risk indexes (RI): chemical (ChemRI), ecotoxicological (EcotoxRI), ecological (EcoRI).

had high levels of heavy metal contaminants such as $\mathrm{Pb}$ and $\mathrm{Zn}$. The concentrations of heavy metals in Issyk-Kul soils had the following increasing order: $\mathrm{Zn}>\mathrm{Pb}>\mathrm{Cu}>\mathrm{Cd}$. From the calculated indexes the western zone is moderately enriched with $\mathrm{Pb}$. This zone is a transportation hub of all the automobile roads in this region, which confirms the probability the predominance of this metal. The geoacumulation index shows that all zones are extremely contaminated with $\mathrm{Zn}, \mathrm{Pb}$ and $\mathrm{Cu}$, while pollution for $\mathrm{Cd}$ is moderate. High Igeo values were obtained for $\mathrm{Zn}$ for all sampling sites. The zinc content in the four zones is arranged in the following order: east $>$ south $>$ north $>$ west. The entry of zinc into the soil is associated with the use of various fertilizers used in agriculture and in the burning of coal [28-29]. It should be noted that coal mining is being developed in the eastern province of Dzhergalan, which affects the predominance of zinc in the eastern zone. Contamination factor in all zones reveled moderate contamination, with $\mathrm{Pb}, \mathrm{Zn}$ and $\mathrm{Cd}$, except in the western zone we obtained low contamination with $\mathrm{Cd}$. Potential ecological risk values for all sampling sites indicated low ecological risk in the soils. The interdisciplinary approach based on the data of chemistry, ecology and toxicology characterizes the soil as strongly disturbed and refers to 4 categories of quality. The Triad approach, which also considers the state of the soil biota, is more informative for a long-term perspective, because biotic components are vulnerable and sensitive to different pollution [30].

\section{Conclusions}

Assessing the ecological condition of soil in urbanized areas is of great importance when conducting environmental monitoring of the condition of soil ecosystems. The correct selection of informative methods that allow for assessing the real condition of the ecosystem is important. Different environmental indexes assessing the condition of urbanized ecosystems showed varying degrees of impact. Indexes such as enrichment factor, contamination factor, geoacumulation, and potential ecological risk indicate mainly soil contamination with certain heavy metals, while the Triads method, which assesses the condition of the environment by three main indicators (chemical, ecotoxicological and bioindicative) makes it possible to most reliably assess the ecological condition of a complex soil ecosystem. The results of this study showed that for a comprehensive assessment of condition of the soil ecosystem, it is important to consider the state of biota as an integral part of the ecosystem being assessed.

\section{Conflict of Interest}

The authors declare no conflict of interest.

\section{References}

1. TURKYILMAZ A., SEVIK H., CETIN M., ELNAJI A. AHMAIDA SALEH. Changes in heavy metal accumulation depending on traffic density in some landscape plants Pol. J. Environ. Stud. 27, 2277, 2018.

2. MONTERROSO C., RODRÍGUEZ F., CHAVES R., DIEZ J. BECERRA-CASTRO C.C., KIDD P.S., MACIAS F. Heavy metal distribution in mine-soils and plants growing in a $\mathrm{Pb} / \mathrm{Zn}$-mining area in NW Spain. Appl. Geochem. 44, 3, 2014.

3. NAWREZ S., CHAREF A., LAMIA A. Assessment of tailings stability and soil contamination of Kef Ettout (NW Tunisia) abandoned mine. Arab. J. Geosci. 12 (73), 2019.

4. OGUNDELE D.T., ADIO A.A., OLUDELE O.E. Heavy metal concentrations in plants and soil along heavy traffic roads in North Central Nigeria. J. Environ. Anal. Toxicol. $5,2015$.

5. ZHANG M., LI X., YANG R., WANG J., AI Y., GAO Y., ZHANG Y., ZHANG X., YAN X., LIU B., YU H. Multipotential toxic metals accumulated in urban soil and street dust from Xining city, NW China: spatial occurrences, sources, and health risks. Arch. Environ. Contam. Toxicol. 76, 308, 2019.

6. KAYA I., GÜLSER F. Determining heavy metal contents of hollyhock (Alcea rosea L.) in roadside soils of a Turkish lake basin. Pol. J. Environ. Stud. 27, 2081, 2018.

7. DECENA S.C.P., ARGUILLES M.S., ROBEL L.L. Assessing heavy metal contamination in surface sediments in an urban river in the Philippines. Pol. J. Environ. Stud. 27, 1983-9-1995 2018.

8. GONZÁLEZ-TERREROS E., MANUEL RUÍZVALDIVIEZO V., GALVÁN-VELÁZQUEZ A., OLIVIA FRANCO-HERNÁNDEZ M., L. LUNA-GUIDO M., DENDOOVEN L. Heavy metals in mine-tailing soil mixtures cultivated with Ricinus communis L. Pol. J. Environ. Stud. 27, 2007, 2018.

9. WANG S., ZHAO Y., GUO J., ZHOU L. Effects of Cd, Cu and $\mathrm{Zn}$ on Ricinus communis L. Growing in single element or co-contaminated soils: Pot experiments. Ecol. Eng. 90, 347, 2016.

10. National statistical committe of the Kyrgyz republic 20132017. 
11. KALDYBAEV B.K., DZHENBAEV B.M. Biogeochemical assessment of natural and man-made ecosystems of IssykKul. Bulletin KazNU Al-Farabi. 28, 56, 2010.

12. KADYROVA G.B., KALDYBAEV B.K. Biogeochemistry of lead in soils in the area of lead Ichki-Chat deposits. Izvestiya Vuzov - Bishkek, 4, 96, 2013.

13. BHUIYAN M.A., PARVEZ L., ISLAM M.A., DAMPARE S.B., SUZUKI S. Heavy metal pollution of coal mineaffected agricultural soils in the northern part of Bangladesh. J Hazard Mater 173, 384, 2010.

14. LI F., ZHANG J., HUANG J., HUANG D., YANG J., SONG Y., ZENG G. Heavy metals in road dust from Xiandao District, Changsha City, China: characteristics, health risk assessment, and integrated source identifcation. Environ. Sci. Pollut. Res. 23, 13100, 2016.

15. LI X., FENG L. Geostatistical analyses and fractionation of heavy metals in urban soil from industrial district in Weinan, NW China. Environ. Earth. Sci. 67, 2129, 2012.

16. SUTHERLAND R.A. Bed sediment-associated trace metals in an urban stream, Oahu, Hawaii. Environ. Geol. 39, 611, 2000.

17. MÜLLER G. Die Schwermetallbelastung der Sedimenten des Neckars und Seiner Nebenfüsse. Chemiker-Zeitung. 6, 157, 1981.

18. HAKANSON L. An ecological risk index for aquatic pollution control. A sedimentological approach. J. Water. Res. 14, 975, 1980.

19. TOMLINSON D.L, WILSON J.G, HARRIS C.R, JEFFREY D.W. Problems in the assessment of heavymetal levels in estuaries and the formation of a pollution index. Helgol. Meeresunters. 33, 566, 1980.

20. XU Z., NI S., TUO X., ZHANG C. Calculation of heavy metals' toxicity coefcient in the evaluation of potential ecological risk index. Environ. Sci. Technol. 31, 112, 2008.

21. DAGNINO A., SFORZINI S., DONDERO F., FENOGLIO S., BONA E., JENSEN J., VIARENGO A. A weight of evidence approach for the integration of environmental "triad" data to assess ecological risk and biological vulnerability. Integr. Environ. Assess. Managem. 4, 314, 2008.

22. TEREKHOVA V.A., PUKALCHIKA M.A., YAKOVLEV S. The Triad approach to ecological assessment of urban soils. Eurasian Soil Sci. 47, 952, 2014.

23. TEREKHOVA V.A. Soil Bioassay: Problems and approaches. Eurasian Soil Sci. 44, 173, 2011.

24. VOROBEICHIK E.L., SADYKOV O.F., FARAFONTOV M.G. Ecological regulation of technogenic pollution of terrestrial ecosystems (local level). Ekaterinburg: Ufa. 1994.

25. YAKOVLEV A.S., MAKAROV O.A. Ecological assessment, ecological norming, and reclamation of land: major terms and definitions. Use and protection of natural resources in Russia. 87, 64, 2006.

26. KUMAR G.H., KUMARI J.P. Heavy metal lead influative toxicity and its assessment in phytoremediating plants a review. Water Air Soil Poll. 226, 324, 2015.

27. BABINCEV L.M. Heavy metals in soil and application of new plant materials in the process of phytoremediation. J. Bioremediat. Biodegrad. 8, 413, 2017.

28. LIANG J., FENG C., ZENG G., GAO X., ZHONG M., LI X., LI X., HE X., FANG Y. Spatial distribution and source identification of heavy metals in surface soils in a typical coal mine city, Lianyuan, China. Environ Pollut. 225, 681, 2017.

29. TANG X., XIA M., GUAN F., FAN S. Spatial distribution of soil nitrogen, phosphorus and potassium stocks in Moso bamboo forests in subtropical China. Forests 7, 267, 2016.

30. TEREKHOVA V.A., VORONINA L.P., NIKOLAEVA O.V., BARDINA T.V., KALMATSKAYA O.A., KIRYUSHINA A.P., UCHANOV P.V., KRESLAVSKIY V.D., VASILYEVA G.K. Application of phytotest in ecological soil science. Use and protection of natural resources of Russia, 3, 37, 2016. 
